\title{
LECT2 promotes inflammation and insulin resistance in adipocytes via P38 pathways
}

\author{
Tae Woo Jung', Yoon Hee Chung'2, Hyoung-Chun Kim³, A M Abd El-Aty4,5 and Ji Hoon Jeong6 \\ 1Research Administration Team, Seoul National University Bundang Hospital, Gyeonggi, Republic of Korea \\ 2Department of Anatomy, College of Medicine, Chung-Ang University, Seoul, Republic of Korea \\ ${ }^{3}$ Neuropsychopharmacology and Toxicology Program, College of Pharmacy, Kangwon National University, Chunchon, Republic of Korea \\ ${ }^{4}$ Department of Pharmacology, Faculty of Veterinary Medicine, Cairo University, Giza, Egypt \\ ${ }^{5}$ Department of Medical Pharmacology, Medical Faculty, Ataturk University, Erzurum, Turkey \\ ${ }^{6}$ Department of Pharmacology, College of Medicine, Chung-Ang University, Seoul, Republic of Korea
}

Correspondence should be addressed to J H Jeong or A M Abd El-Aty: jhjeong3@cau.ac.kr or abdelaty44@hotmail.com

\begin{abstract}
Leukocyte cell-derived chemotaxin 2 (LECT2) is a recently identified novel hepatokine

Key Words that causes insulin resistance in skeletal muscle by activating c-Jun $\mathrm{N}$-terminal kinase (JNK), thereby driving atherosclerotic inflammation. However, the role of LECT2 in inflammation and insulin resistance in adipocytes has not been investigated. In this study, we report that LECT2 treatment of differentiated 3T3-L1 cells stimulates P38 phosphorylation in a dose-dependent manner. LECT2 also enhanced inflammation

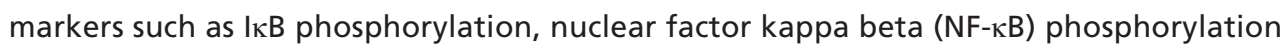
and IL-6 expression. Moreover, LECT2 treatment impaired insulin signaling in differentiated 3T3-L1 cells, as evidenced by the decreased levels of insulin receptor substrate (IRS-1) and Akt phosphorylation and reduced insulin-stimulated glucose uptake. Furthermore, LECT2 augmented lipid accumulation during 3T3-L1 cell differentiation by activating SREBP1c-mediated signaling. All these effects were significantly abrogated by siRNA-mediated silencing of P38, CD209 expression or a JNK inhibitor. Our findings suggest that LECT2 stimulates inflammation and insulin resistance in adipocytes via activation of a CD209/P38-dependent pathway. Thus, these results suggest effective therapeutic targets for treating inflammation-mediated insulin resistance.

- LECT2

- P38

- NF-kB

- inflammation

- insulin resistance

- adipocyte

\section{Introduction}

The main features of adipose tissue dysfunction in obesity and metabolic syndrome are chronic lowgrade inflammation in adipose tissue and macrophage infiltration (Hajer et al. 2008, Bluher 2009). The large numbers of macrophages and $\mathrm{T}$ cells that infiltrate adipose tissue stimulate inflammation, which is thought to alter adipose tissue function, leading to metabolic disorders and systemic insulin resistance (Olefsky \& Glass 2010, Sun et al. 2012). Various proinflammatory cytokines secreted by adipocytes and infiltrated macrophages have been shown to cause insulin resistance (Xu et al. 2003), suggesting that infiltrated macrophages in adipose tissue play an important role in obesity and that macrophagemediated inflammatory responses may induce the development of obesity-related insulin resistance.

Leukocyte cell-derived chemotaxin 2 (LECT2) is a secretory protein that was discovered in a screen for novel neutrophil chemotactic factors (Yamagoe etal. 1996). LECT2 
is mainly produced by the liver, where it is released into the bloodstream (Yamagoe et al. 1998). LECT2-knockout mice demonstrated impaired homeostasis of hepatic natural killer $\mathrm{T}$ cells, resulting in severe hepatitis (Saito et al. 2004). Furthermore, LECT2 has shown anti-inflammatory and tumor-suppressive effects against $\beta$-catenin-induced hepatic carcinogenesis (Anson et al. 2012) and has been reported to attenuate activation of macrophage-induced bacterial sepsis via the CD209 receptor (Lu et al. 2013). More recently, however, LECT2 has been documented to promote atherosclerotic inflammatory processes through CD209-mediated signaling in human endothelial cells (Hwang et al. 2015a), implying that LECT2 also has proinflammatory properties. Lan et al. reported that LECT2 knockout increased insulin sensitivity in the muscles of mice. They also demonstrated that treatment of $\mathrm{C} 2 \mathrm{C} 12$ cells with recombinant LECT2 impaired insulin signaling by acting on c-Jun $\mathrm{NH}_{2}$-terminal kinase (Lan et al. 2014). Although LECT2 has been demonstrated to attenuate fatty changes and insulin resistance in the liver, the effects of LECT2 on inflammation and insulin signaling in adipocytes remain to be elucidated (Hwang et al. 2015b).

The MAPkinase P38 stimulates adipocyteinflammation in $\beta$-adrenergic receptor-activated adipocytes through the hormone-sensitive lipase-mediated lipolytic pathway with proinflammatory cytokines (Mottillo et al. 2010). In addition, P38-ERK1/2-mediated signaling has been documented to play an essential role in IL-1 $\beta$-induced insulin resistance in mouse adipocytes (Jager et al. 2007). Furthermore, P38 activation promotes visceral adiposity-related whole-body insulin resistance (Bluher et al. 2009). These findings suggest that P38 plays a crucial role in inflammation and insulin resistance in adipocytes. Therefore, we hypothesized that LECT2 causes inflammation and insulin resistance in adipocytes.

Here, we investigated (1) the effect of LECT2 on inflammation and insulin resistance in differentiated 3T3-L1 cells and (2) the mechanisms of LECT2-mediated stimulation of inflammation and insulin resistance through CD209/P38/NF-кB-dependent signaling.

\section{Materials and methods}

\section{Cell culture, reagents and antibodies}

3T3-L1 mouse preadipocytes (ATCC) were cultured in DMEM (Invitrogen) supplemented with $10 \%$ fetal bovine serum (Invitrogen), 100 units $/ \mathrm{mL}$ penicillin and $100 \mu \mathrm{g} / \mathrm{mL}$ streptomycin (Invitrogen). Cells were cultured in a humidified atmosphere of $5 \% \mathrm{CO}_{2}$ at $37^{\circ} \mathrm{C}$. Differentiation was induced $48 \mathrm{~h}$ after reaching confluence (day 2) by cultivation in culture medium supplemented with $1 \mu \mathrm{M}$ insulin, $0.5 \mathrm{mM}$ IBMX (Sigma) and $0.5 \mu \mathrm{g} / \mathrm{mL}$ dexamethansone for 2 days and thereafter in DMEM supplemented with $1 \mu \mathrm{M}$ insulin for another couple of days. Subsequently, cells were maintained in and refed every 2 days with fresh culture medium(6 days after initiation of differentiation). The differentiated 3T3-L1 cells were treated with $0-500 \mathrm{ng} / \mathrm{mL}$ LECT2 (Abcam) and $10 \mu \mathrm{M} \mathrm{SP} 600125$ (Abcam) for $24 \mathrm{~h}$. Insulin $(10 \mathrm{nM})$ was used to stimulate insulin signaling (insulin receptor substrate (IRS-1)) and Akt for $3 \mathrm{~min}$. Anti-phospho IRS-1 (1:1000), anti-IRS-1 (1:1000), anti-phospho Akt (1:1000), anti-Akt (1:1000), anti-phospho P38 (1:1000), anti-P38 (1:1000), anti-phospho NF-кB p65, anti-NF-кB p65 (1:2500), antiphospho IкB (1:1000), anti-IкB (1:1000), anti-phospho JNK (1:1000) and anti-JNK (1:1000) antibodies were purchased from Cell Signaling Technology. Anti-IL-6 (1:2000), anti-CD209 (1: 1000) and anti- $\beta$-actin (1:5000) antibodies were obtained from Santa Cruz Biotechnology.

\section{Western blot analysis}

Differentiated 3T3-L1 cells were harvested and lysed with PRO-PREP buffer (Intron Biotechnology, Seoul, Republic of Korea) for $60 \mathrm{~min}$ at $4^{\circ} \mathrm{C}$ to generate protein extracts. Proteins $(30 \mu \mathrm{g})$ were resolved by SDS-PAGE on $12 \%$ gels and transferred to nitrocellulose membranes (Amersham Bioscience). The membranes were probed with the indicated primary antibodies, followed by secondary antibodies conjugated with horseradish peroxidase (Santa Cruz Biotechnology). Immunoreactive signals were detected using an ECL kit (Amersham Bioscience).

\section{RNA extraction and quantitative real-time PCR}

Total RNA was isolated from harvested hepatocytes using TRIzol reagent (Invitrogen). Gene expression was measured by quantitative real-time PCR (qPCR) using a fluorescent TaqMan 5'nuclease assay with an Applied Biosystems 7000 sequence detection system. The qPCR reactions included cDNA, 2× TaqMan Master Mix and 20× premade TaqMan gene expression assays (Applied Biosystems). The thermocycling conditions were $95^{\circ} \mathrm{C}$ for $10 \mathrm{~min}$, followed by 40 cycles of $95^{\circ} \mathrm{C}$ for $15 \mathrm{~s}$ and $60^{\circ} \mathrm{C}$ for $1 \mathrm{~min}$. PCR primer mixes for mouse SCD1 (MP201188; Sino Biological) were used. Mouse SREBP1c mRNA was quantified using the following primers: 5'-cggaagctgtcggggtag-3' 
and 5'-gttgttgatgagctggagca-3'. Mouse $\beta$-actin mRNA was quantified as an endogenous control, using the following primers: 5'-CGATGCTCCCCGGGCTGTAT-3' and 5'-TGGGGTACTTCAGGGTCAGG-3'.

\section{Transfection with siRNAs for gene silencing in cells}

siRNA oligonucleotides $(20 \mathrm{nM})$ specific for P38 (a; SC-29434, b; SC-39117, c; SC-39014) and CD209 (a; SC-42857, b; SC-42858, c; SC-142186) were purchased from Santa Cruz Biotechnology. To suppress gene expression, cells were transfected with Lipofectamine 2000 (Invitrogen) according to the manufacturer's instructions. In brief, 3T3-L1 preadipocytes were differentiated, grown to $60-70 \%$ confluence, and then serum starved for $12 \mathrm{~h}$. The cells were then transfected with validated siRNA or scrambled siRNA at a final concentration of $20 \mathrm{nM}$ in the presence of the transfection reagent. At $24 \mathrm{~h}$ after transfection, the cells were harvested for protein extraction and additional analyses. We performed transfection twice using DeliverX Plus (Panomics, Freemont, CA, USA) to examine the effect of LECT2 on lipid accumulation and lipogenic genes mRNA expression during differentiation period (Supplementary Fig. 1, see section on supplementary data given at the end of this article). In brief, 3T3-L1 preadipocytes were cultured in $2 \%$ bovine calf serum (BCS) for $6 \mathrm{~h}$ before transfection. The cells were then transfected with validated siRNA or scrambled siRNA at a final concentration of $20 \mathrm{nM}$ in the presence of the transfection reagent (day -1). At $72 \mathrm{~h}$ after the first transfection, the cells were transfected with siRNA at a final concentration of $10 \mathrm{nM}$ in the presence of the transfection reagent again (day 2). At 72-96h after second transfection, differentiated 3T3-L1 cells were harvested for protein and mRNA extraction and stained with Oil red-O (day 6).

\section{Measurement of glucose uptake and acetyl-CoA and ATP content}

Glucose uptake levels were measured using the Glucose Uptake Assay Kit (Abcam). Briefly, proliferating and differentiating 3T3-L1 cells were seeded at $5 \times 10^{5}$ cells/well in black-walled clear bottom 96-well plates (Corning) in DMEM containing 10\% FBS. Upon reaching a confluency of $95 \%$, differentiation was induced with differentiating media. After $48 \mathrm{~h}$, media was changed to media containing 0-500 ng/mL LECT2 for $24 \mathrm{~h}$. Following treatment, media was removed from wells and cells were treated with $10 \mathrm{nM}$ insulin and $1 \mathrm{mM}$ 2-deoxyglucose (2-DG) for $30 \mathrm{~min}$. Afterward, plates were centrifuged for $1 \mathrm{~min}$ at $30 \boldsymbol{g}$ and incubated for $1 \mathrm{~h}$ at room temperature. After 2-DG taken up by the cells was extracted using the Glucose Uptake Assay Kit extraction buffer, 2-DG uptake levels were measured at a wavelength of OD $412 \mathrm{~nm}$ on a BioTek Synergy HT plate reader (BioTek Instruments). Intracellular levels of acetyl-CoA were measured in differentiated 3T3-L1 cells using a PicoProbe Acetyl CoA Assay Kit (Abcam), while intracellular ATP levels were measured using an ATP Assay Kit (Abcam) according to the manufacturer's instructions.

\section{Oil red-O staining and triglyceride (TG) assay}

Differentiated 3T3-L1 cells were stained using the Oil Red-O method to measure the accumulated cellular neutral lipids, including TG. After fixation with 10\% formalin for $40 \mathrm{~min}$, adipocytes were stained with the Oil Red-O solution (Sigma) for $1 \mathrm{~h}$ at $37^{\circ} \mathrm{C}$. Oil Red-O stained TG content was quantified by adding isopropanol to each sample. The mixtures were gently agitated at $25^{\circ} \mathrm{C}$ for $8 \mathrm{~min}$. At last, $100 \mu \mathrm{L}$ isopropanol-extracted samples were analyzed by a spectrophotometer at $510 \mathrm{~nm}$.

\section{Statistical analysis}

Results are presented as the fold of the highest values (means \pm s.E.M.s). All experiments were performed at least three times. Student's $t$ test or two-way ANOVA was used for statistical analysis. All analyses were performed using the SPSS/PC statistical program (version 12.0 for Windows; SPSS).

\section{Results}

LECT2 induces inflammation in differentiated 3T3-L1 cells through a CD209/P38-dependent pathway

Since P38 is a key regulator of the pro-inflammatory response (Schieven 2005, Olson et al. 2007, Ulivi et al. 2008), we next evaluated the effect of LECT2 on P38 phosphorylation in differentiated 3T3-L1 cells. We found that LECT2 stimulated P38 phosphorylation in a dose-dependent manner (Fig. 1A). LECT2 increases inflammatory markers, such as phosphorylation of NF- $\mathrm{B}$ and $\mathrm{I} \kappa \mathrm{B}$ and TNF $\alpha$ and MCP-1 release from differentiated 3T3-L1 cells (Figs $1 \mathrm{~B}$ and 2A). We then investigated whether LECT2-induced P38 phosphorylation is associated with the stimulation of inflammation in differentiated 3T3-L1 cells. The receptor CD209 is required for LECT2 to elicit 

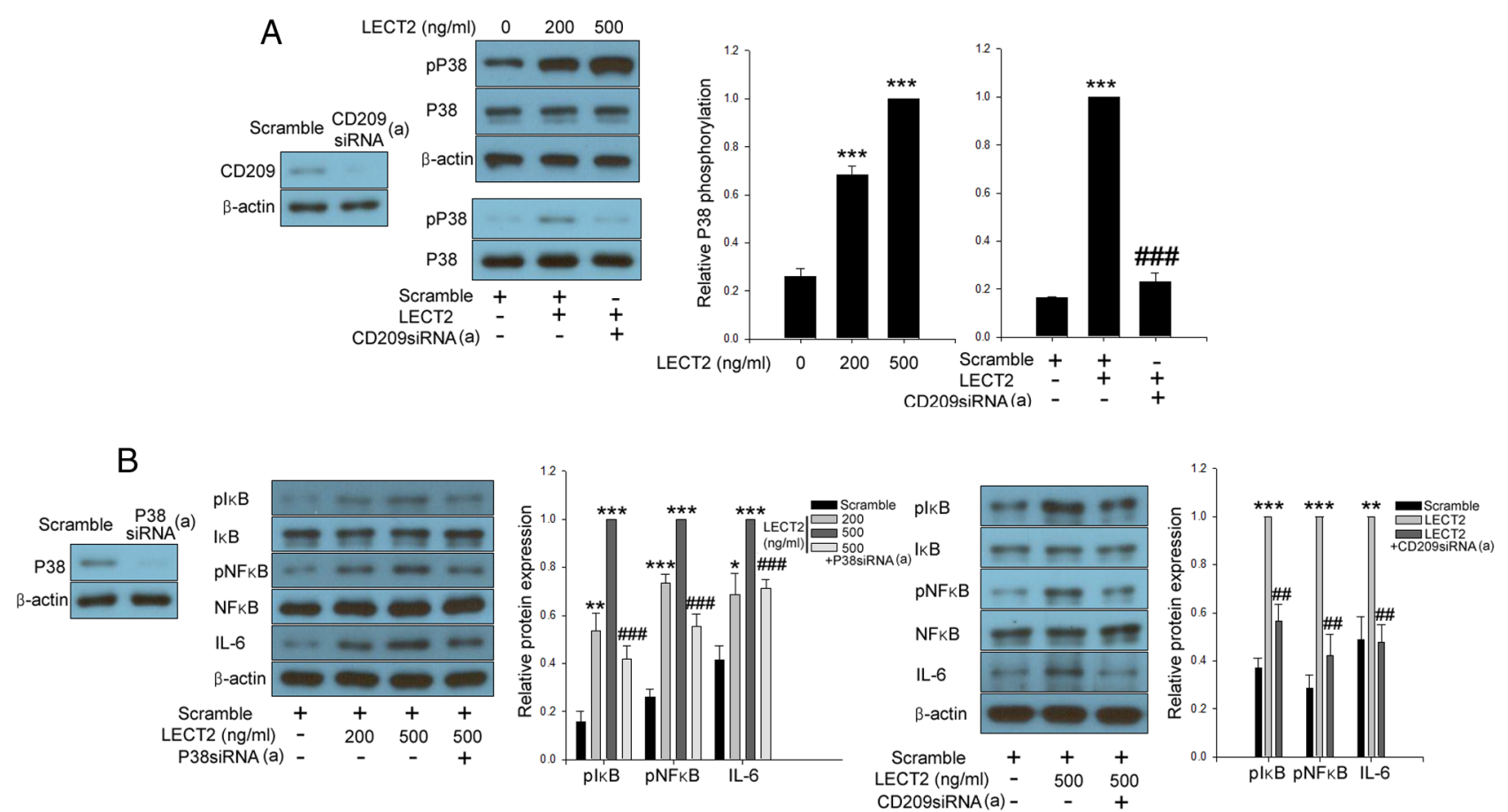

Figure 1

LECT2 promotes inflammatory responses in differentiated 3T3-L1 cells via CD209/P38 signaling. (A) Western blot analysis of P38 phosphorylation in differentiated 3T3-L1 cells treated with LECT2 (0-500 ng/mL) or transfected with CD209 siRNA (a) for $24 \mathrm{~h}$. (B) Western blot analysis of NF- $\mathrm{KB}$ and IKB phosphorylation and IL-6 expression in differentiated 3T3-L1 cells transfected with siRNAs (a) targeting P38 or CD209 that were treated with LECT2 $\left(0-500 \mathrm{ng} / \mathrm{mL}\right.$ ) for $24 \mathrm{~h}$. Means \pm S.E.M. were calculated using data obtained from three independent experiments. ${ }^{* * *} P<0.001$ and ${ }^{* *} P<0.01$ compared to

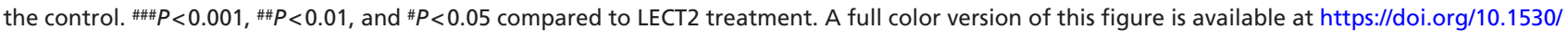
JME-17-0267.

a pro-inflammatory response (Lu et al. 2013, Hwang et al. 2015a, Shen et al. 2016). Suppression of CD209 by siRNA abrogated the effect of LECT2 on P38 phosphorylation (Fig. 1A). siRNA-mediated suppression of both P38 and CD209 abrogated the effects of LECT2 on inflammation (Figs 1B and 2A). To exclude the off target effects, we also tested different P38 and CD209 siRNAs and demonstrated same results (Fig. 2B).

\section{LECT2 impairs insulin signaling and insulin-stimulated glucose uptake in differentiated 3T3-L1 cells through a CD209/P38- mediated pathway}

LECT2 treatment impaired insulin-stimulated IRS-1 and Akt phosphorylation (Fig. 3A) and also decreased glucose uptake (Fig. 3B) in differentiated 3T3-L1 cells. We also examined whether LECT2-induced P38 phosphorylation affected the development of insulin resistance in differentiated 3T3-L1 cells. As shown in Fig. 3, the effects of LECT2 on insulin resistance were significantly blocked by siRNA-mediated silencing of P38 and CD209. To exclude the off target effects, we also tested different P38 and CD209 siRNAs and demonstrated same results (Fig. 3C).

\begin{tabular}{|lr}
\hline $\begin{array}{l}\text { http://jme.endocrinology-journals.org } \\
\text { https://doi.org/10.1530/JME-17-0267 }\end{array}$ & $\begin{array}{r}\text { ( } 2018 \text { Society for Endocrinology } \\
\text { Published by Bioscientifica Ltd. } \\
\text { Printed in Great Britain }\end{array}$
\end{tabular}

\section{LECT2 stimulates lipogenesis in 3T3-L1} pre-adipocytes via CD209/p38-dependent signaling

LECT2 has been reported to be associated with SREBP1mediated hepatic lipogenesis (Hwang et al. 2015b). Therefore, we examined the effect of LECT2 on the differentiation of 3T3-L1 cells. Microscopic evaluation demonstrated that treatment of 3T3-L1 cells with recombinant mouse LECT2 markedly enhanced lipid accumulation (Fig. 4A) and upregulated the mRNA expression of lipogenesis-related genes such as SREBP1c and SCD1 (Fig. 4B). Since P38 has been reported to play an essential role in the differentiation of 3T3-L1 cells (Engelman et al. 1998), we next evaluated the roles of P38 and its receptor CD209 in LECT2-induced lipid accumulation. siRNAs targeting P38 or CD209 significantly reversed these changes (Fig. 4).

\section{LECT2 induces inflammation and insulin resistance through JNK-mediated pathway}

It has been reported that JNK contributes to LECT2induced inflammation and insulin signaling impairment (Lan et al. 2014, Hwang et al. 2015a). Therefore, we next 


\begin{tabular}{l|l|l|c|c|}
$\begin{array}{l}\text { Journal of Molecular } \\
\text { Endocrinology }\end{array}$ & T W Jung et al. & $\begin{array}{l}\text { LECT2 promotes inflammation } \\
\text { and insulin resistance }\end{array}$ & $\mathbf{6 1 : 1}$ & 41 \\
\hline
\end{tabular}
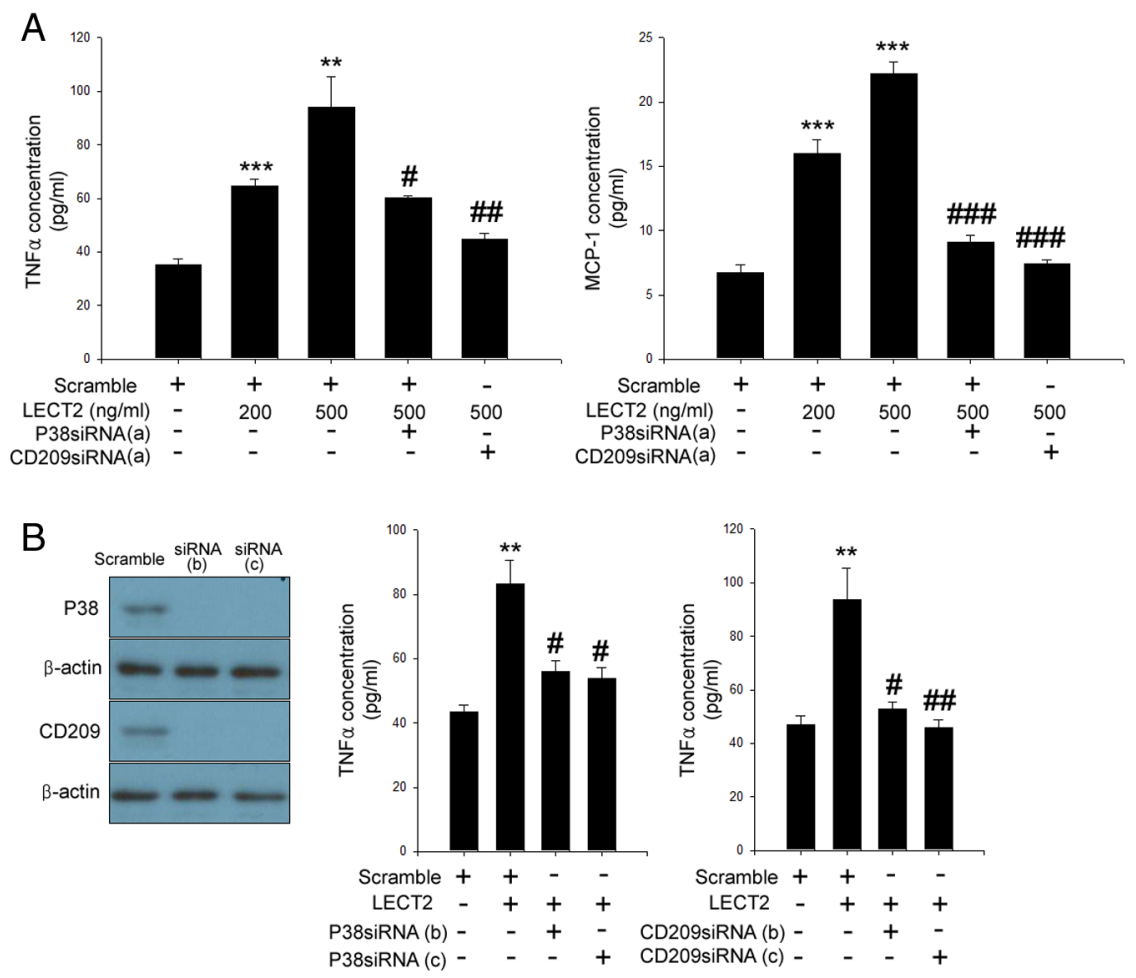

Figure 2

LECT2 induces the secretion of pro-inflammatory cytokines in differentiated 3T3-L1 cells through CD209/P38-dependent pathway. Culture media analysis of TNF $\alpha$ and MCP-1 in differentiated 3T3-L1 cells transfected with siRNA (a) (A) and different siRNAs ( $b$ and $c$ ) (B) targeting P38 or CD209 that were treated with LECT2 (0-500 ng/ $\mathrm{mL}$ ) for $24 \mathrm{~h}$. Means \pm s.E.M. were calculated using data obtained from three independent experiments. ${ }^{* *} P<0.001$ and ${ }^{* *} P<0.01$ compared to the control. $\# \# P<0.001, \# \# P<0.01$ and $\# P<0.05$ compared to LECT2 treatment. A full color version of this figure is available at https://doi. org/10.1530/JME-17-0267. examined the effects of LECT2 on JNK phosphorylation in differentiated 3T3-L1 cells. LECT2 stimulated JNK phosphorylation in a dose-dependent manner (Fig. 5A). Furthermore, suppression of JNK by SP600125, a specific JNK inhibitor reversed LECT2-induced NF-кB and ІкB phosphorylation (Fig. 5B) and impairment of insulinstimulated IRS-1 and Akt phosphorylation (Fig. 5C).

\section{LECT2 does not decrease fatty acid oxidation}

It has been reported that incomplete fatty acid oxidation causes insulin resistance (Zhang et al. 2010). Therefore, we examined the effect of LECT2 on fatty acid oxidation. As shown in Fig. 6, LECT2 did not affect intracellular acetylCoA and intracellular ATP levels in differentiated 3T3-L1 cells (Fig. 6).
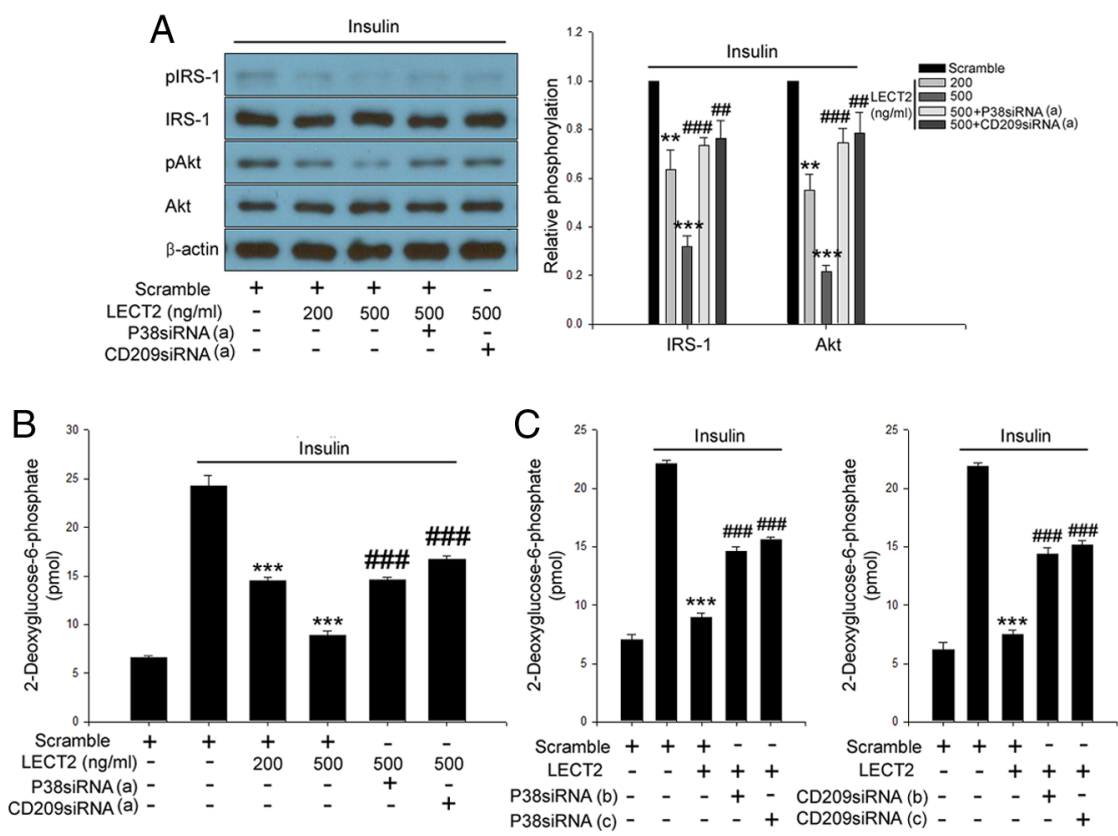

Figure 3

LECT2 induces insulin resistance in differentiated 3T3-L1 cells via a CD209/P38-mediated pathway. (A) Western blot analysis of phosphorylation of IRS-1 and Akt in differentiated 3T3-L1 cells transfected with $\mathrm{P} 38$ or $\mathrm{CD} 209$-targeting siRNAs (a) treated with and LECT2 $(0-500 \mathrm{ng} / \mathrm{mL})$ for $24 \mathrm{~h}$. Human insulin (10 nM) stimulated IRS-1 and Akt phosphorylation after $3 \mathrm{~min}$. (B) 2-Deoxyglucose uptake in scramble, P38 or CD209 siRNAs

(a)-transfected differentiated 3T3-L1 cells treated with LECT2 (0-500 ng/mL) for $24 \mathrm{~h}$. (C)

2-Deoxyglucose uptake in scramble, different P38 or CD209 siRNAs (b and c)-transfected differentiated 3T3-L1 cells treated with LECT2 $(0-500 \mathrm{ng} / \mathrm{mL})$ for $24 \mathrm{~h}$. Human insulin $(10 \mathrm{nM})$ was used to stimulate glucose uptake for $30 \mathrm{~min}$.

Means \pm S.E.M. were calculated from data obtained from three independent experiments. ${ }^{* * *} P<0.001$ and ${ }^{* *} P<0.01$ compared to insulin treatment. $\# \# P<0.001$ and $\# P<0.01$ compared to insulin + LECT2 treatment. A full color version of this figure is available at https://doi.org/10.1530/ JME-17-0267. 
A
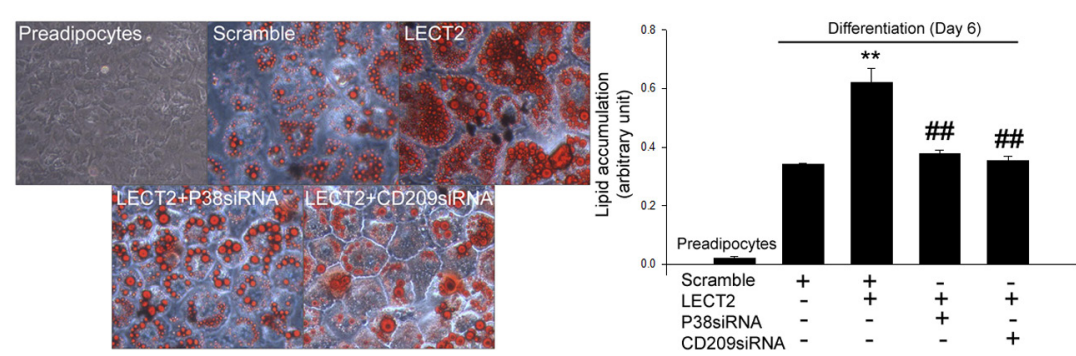

\section{Figure 4}

LECT2 stimulates lipid accumulation in 3T3-L1 cells during differentiation. (A) Oil-red $O$ staining in differentiated $3 \mathrm{~T} 3 \mathrm{-L} 1$ cells in the presence of LECT2 $(500 \mathrm{ng} / \mathrm{mL})$ for 6 days. Lipid accumulation was quantitated using an isopropanol extraction method. (B) Quantitative real-time PCR analysis of SREBP1C and SCD1 mRNA expression in
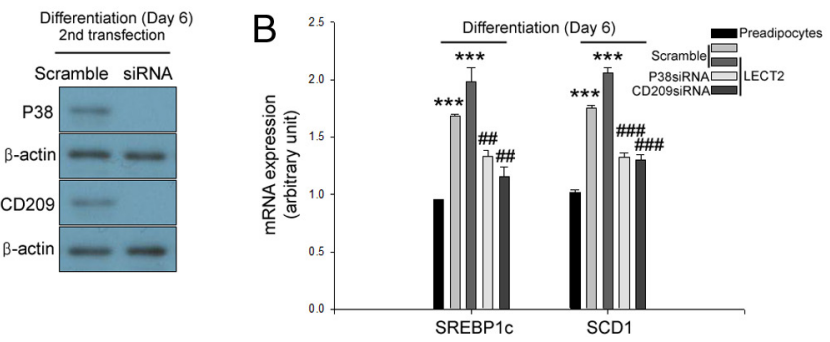
differentiated 3T3-L1 cells treated with LECT2 $(0-500 \mathrm{ng} / \mathrm{mL})$ for 6 days. Transfections were performed two times during 3T3-L1 differentiation (Supplementary Fig. 1). Means \pm S.E.M. were obtained from three separate experiments. ${ }^{* *} P<0.001$ and ${ }^{* *} P<0.01$ compared to the control. \#\#P<0.001 and \#P<0.01 compared to LECT2 treatment. A full color version of this figure is available at https://doi. org/10.1530/JME-17-0267.

\section{Discussion}

Obesity induces a low-grade chronic inflammatory response and stimulates systemic inflammation by elevating proinflammatory cytokine expression. Obesity is also associated with a low-grade chronic inflammatory condition in adipose tissue that is accompanied by infiltration of immune cells such as neutrophils and macrophages (Chawla et al. 2011, Huh et al. 2014). Adipose tissue and invasive macrophages secrete a variety of proinflammatory cytokines that affect further immune cell infiltration, leading to impaired liver and skeletal metabolic homeostasis and ultimately systemic insulin resistance. (Hotamisligil et al. 1993, Weisberg et al. 2003, $\mathrm{Xu}$ et al. 2003). Furthermore, adipose tissue dysfunction caused by chronic inflammation increases the release of free fatty acids (FFAs), thus elevating their serum levels. This is important because FFAs are known to contribute to insulin resistance by interfering with insulin signaling (Boden 1997). Impaired insulin signaling leading to insulin resistance is a main characteristic of metabolic disorders and type 2 diabetes.

LECT2 has been previously documented to show potent pro-inflammatory effects in macrophages (Lu et al. 2013, Shen et al. 2016), endothelial cells (Hwang et al. 2015a) and hepatocytes (Anson et al. 2012). Moreover, LECT2 has been shown to induce insulin resistance in the liver (Hwang et al. 2015b) and in skeletal muscle (Lan et al. 2014). The aim of this study was to investigate the effects of LECT2 on inflammation and insulin resistance in adipocytes. We found that treatment of differentiated 3T3-L1 cells with LECT2 resulted in an NF-kB-mediated pro-inflammatory response. We also found that LECT2 treatment significantly induced the pro-inflammatory cytokines TNF $\alpha$ and MCP-1. These results suggest that the pro-inflammatory effects of LECT2 in adipocytes are likely mediated by stimulation of NF-kB-mediated signaling and activation of downstream molecules.

The phosphatidylinositol 3-kinase (PI3K)/Akt pathway plays a central role in the regulation of various processes
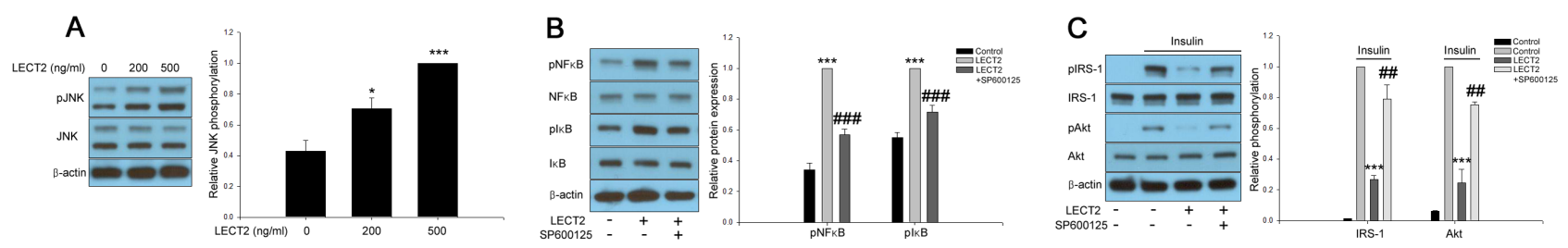

\section{Figure 5}

LECT2 augments JNK phosphorylation, leading to induction of inflammation and insulin resistance. (A) Western blot analysis of JNK phosphorylation in differentiated 3T3-L1 cells treated with and LECT2 $(0-500 \mathrm{ng} / \mathrm{mL})$ for $24 \mathrm{~h}$. (B) Western blot analysis of NF-KB and IKB phosphorylation in differentiated 3T3-L1 cells treated with LECT2 $(0-500 \mathrm{ng} / \mathrm{mL})$ and SP600125 $(10 \mu \mathrm{M})$ for $24 \mathrm{~h}$. (C) Western blot analysis of phosphorylation of IRS-1 and Akt in differentiated 3T3-L1 cells treated with LECT2 $(0-500 \mathrm{ng} / \mathrm{mL})$ and SP600125 $(10 \mu \mathrm{M})$ for $24 \mathrm{~h}$. Human insulin $(10 \mathrm{nM})$ stimulated IRS-1 and Akt phosphorylation after $3 \mathrm{~min}$. Means \pm s.E.M. were obtained from three separate experiments. ${ }^{* \star *} P<0.001$ and ${ }^{*} P<0.05$ compared to the control. ${ }^{\# \# \# P<0.001}$ and \#\#P<0.01 compared to LECT2 treatment. A full color version of this figure is available at https://doi.org/10.1530/JME-17-0267. 

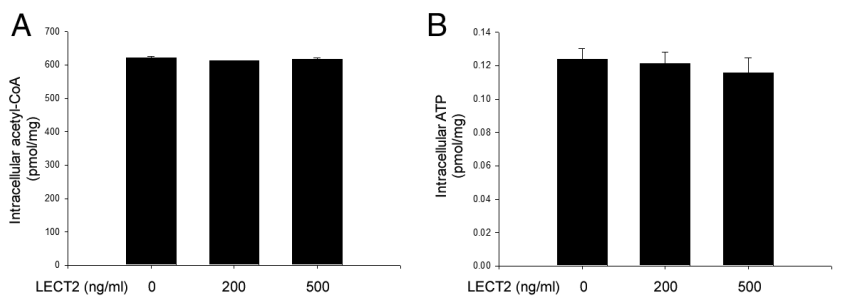

Figure 6

LECT2 does not affect fatty acid oxidation. (A) Intracellular acetyl-CoA and (B) ATP levels in scramble, P38 or CD209 siRNAs-transfected differentiated 3T3-L1 cells treated with LECT2 $(0-500 \mathrm{ng} / \mathrm{mL})$ for $24 \mathrm{~h}$. Means \pm S.E.M. were obtained from three separate experiments.

relying on intracellular signaling such as cell survival, proliferation and differentiation (Sinor \& Lillien 2004). Akt is suppressed under obese conditions because serine residues in IRS- 1 are phosphorylated, thereby impairing the IRS-1-induced PI3K-mediated pathway (Gao et al. 2002) and inhibiting IRS-1-mediated Akt activation (Zick 2005, Guo 2013). Phosphorylation of Akt on Ser473 has been associated with a stronger insulin response in the skeletal muscle of LECT2-knockout mice compared to wild-type mice (Lan et al. 2014). In the current study, we found that LECT2 treatment significantly suppressed insulin signaling and insulin-stimulated glucose uptake. Furthermore, siRNA-mediated suppression of P38 and CD209 markedly abrogated these changes. These results imply that LECT2 impairs insulin sensitivity in adipocytes through a CD209/P38-mediated pathway.

In this study, we found that LECT2 treatment increased the mRNA expression of lipogenic genes (SREBP1C and SCD1), accompanied by increased lipid accumulation in pre-adipocytes. These results suggest that LECT2 may cause obesity and are consistent with a previous study that reported body weight loss in LECT2-knockout mice (Lan et al. 2014). P38-mediated signaling plays a crucial

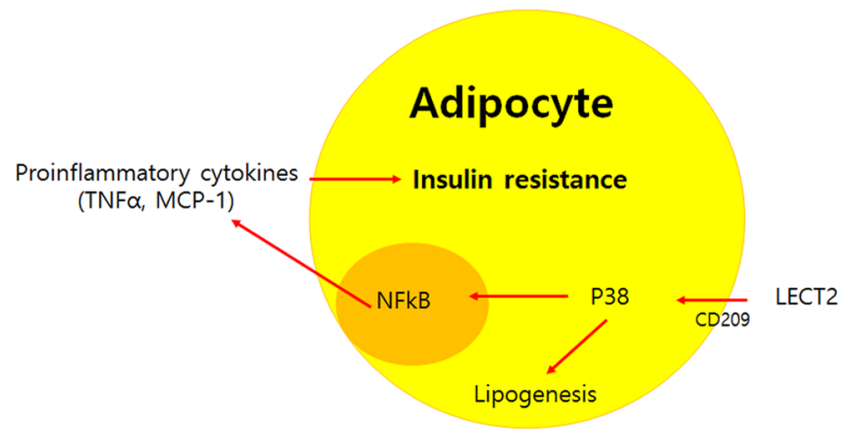

Figure 7

Schematic diagram of the effects of LECT2 on inflammation and insulin resistance in adipocytes. A full color version of this figure is available at https://doi.org/10.1530/JME-17-0267. role in the regulation of energy homeostasis in skeletal muscle (Puigserver et al. 2001), hepatocytes (Cao et al. 2005) and adipocytes (Cao et al. 2001). Since P38 has been reported to suppress SREBP1, a central lipogenic gene in hepatocytes (Foretz et al. 1999), we further examined the involvement of P38 in LECT2-induced lipogenesis in 3T3-L1 adipocytes. Unexpectedly, LECT2 upregulated the mRNA expression of lipogenic genes in a CD209/P38dependent fashion. Further investigation is required to characterize the underlying mechanisms by which LECT2 induces differentiation of 3T3-L1 cells through P38dependent pathways.

In the present study, we suggest CD209/P38dependent pathway as a novel mechanism of the effects of LECT2 on inflammation and insulin resistance in differentiated adipocytes. In addition, LECT2 has been reported to induce activation of NF- $\mathrm{kB}$ in macrophages (Shen et al. 2016) and pro-inflammatory cytokines through CD209 receptor-dependent JNK pathway in human endothelial cells (Hwang et al. 2015a). LECT2 also impairs insulin signaling in hepatocytes (Hwang et al. 2015b) and skeletal muscle through JNKmediated pathway (Lan et al. 2014). Therefore, in the current study, we investigated the effects of LECT2 on JNK phosphorylation in differentiated adipocytes. We found that LECT2 stimulated JNK phosphorylation. Moreover, suppression of JNK activity by a specific JNK inhibitor abrogated the effects of LECT2 on inflammation and insulin resistance. These results suggest that JNK plays an important role in LECT2induced inflammation and insulin resistance in differentiated 3T3-L1 cells, similar with in human endothelial cells and skeletal muscle in previous reports (Lan et al. 2014, Hwang et al. 2015a).

In conclusion, we investigated the effects of LECT2 on fully differentiated 3T3-L1 cells to determine whether LECT2 promotes the inflammatory response in adipocytes and whether it is involved in obesity-induced low-grade chronic inflammation in adipose tissue. This is the first report that LECT2 induces pro-inflammatory processes and decreases insulin sensitivity through CD209/ P38 and JNK-mediated activation of NF-kB-dependent signaling. Furthermore, we found that LECT2 stimulates lipogenesis in 3T3-L1 cells. All these effects of LECT2 on inflammation and insulin resistance are regardless of the impairment of fatty acid oxidation (Fig. 7). Suppression of pro-inflammatory cytokines such as IL-6, TNF $\alpha$ and IL-1 $\beta$, which are secreted by immune cells (Weisberg et al. 2003, Lumeng et al. 2008) and adipocytes (Mohamed-Ali et al. 1997, de Luca \& Olefsky 2008), may have therapeutic 
effects on systemic low-grade chronic inflammation related to metabolic syndrome. Therefore, our findings suggest that LECT2 may be an effective therapeutic target for obesity-associated metabolic disorders, including insulin resistance.

\section{Supplementary data}

This is linked to the online version of the paper at https://doi.org/10.1530/ JME-17-0267.

\section{Declaration of interest}

The authors declare that there is no conflict of interest that could be perceived as prejudicing the impartiality of the research reported.

\section{Funding}

This work was supported by a grant from the National Research Foundation (NRF), which is funded by the Ministry of Science, ICT and Future Planning (2016R1C1B2012674), Republic of Korea.

\section{Author contribution statement}

T W J, Y H J, H C K, A A E, and J H J: substantial contribution to conception and design; T W J and J H J: acquisition of data, analysis and interpretation of data; H CK: drafting and revising of the manuscript. All authors approved the final version of the manuscript. $\mathrm{T} \mathrm{W} \mathrm{J}$ and $\mathrm{J} \mathrm{H} \mathrm{J}$ are responsible for the integrity of the work as a whole.

\section{References}

Anson M, Crain-Denoyelle AM, Baud V, Chereau F, Gougelet A, Terris B, Yamagoe S, Colnot S, Viguier M, Perret C, et al. 2012 Oncogenic beta-catenin triggers an inflammatory response that determines the aggressiveness of hepatocellular carcinoma in mice. Journal of Clinical Investigation 122 586-599. (https://doi.org/10.1172/JCI43937)

Bluher M 2009 Adipose tissue dysfunction in obesity. Experimental and Clinical Endocrinology and Diabetes 117 241-250. (https://doi. org/10.1055/s-0029-1192044)

Bluher M, Bashan N, Shai I, Harman-Boehm I, Tarnovscki T, Avinaoch E, Stumvoll M, Dietrich A, Kloting N \& Rudich A 2009 Activated Ask1MKK4-p38MAPK/JNK stress signaling pathway in human omental fat tissue may link macrophage infiltration to whole-body Insulin sensitivity. Journal of Clinical Endocrinology and Metabolism 94 2507-2515. (https://doi.org/10.1210/jc.2009-0002)

Boden G 1997 Role of fatty acids in the pathogenesis of insulin resistance and NIDDM. Diabetes 46 3-10. (https://doi.org/10.2337/ diab.46.1.3)

Cao W, Medvedev AV, Daniel KW \& Collins S 2001 beta-adrenergic activation of p38 MAP kinase in adipocytes: cAMP induction of the uncoupling protein 1 (UCP1) gene requires p38 MAP kinase. Journal of Biological Chemistry 276 27077-27082. (https://doi.org/10.1074/ jbc.M101049200)

Cao W, Collins QF, Becker TC, Robidoux J, Lupo EG Jr, Xiong Y, Daniel KW, Floering L \& Collins S 2005 p38 Mitogen-activated protein kinase plays a stimulatory role in hepatic gluconeogenesis. Journal of Biological Chemistry 280 42731-42737. (https://doi. org/10.1074/jbc.M506223200)
Chawla A, Nguyen KD \& Goh YP 2011 Macrophage-mediated inflammation in metabolic disease. Nature Reviews Immunology 11 738-749. (https://doi.org/10.1038/nri3071)

de Luca C \& Olefsky JM 2008 Inflammation and insulin resistance. FEBS Letters 582 97-105. (https://doi.org/10.1016/j.febslet.2007.11.057)

Engelman JA, Lisanti MP \& Scherer PE 1998 Specific inhibitors of p38 mitogen-activated protein kinase block 3T3-L1 adipogenesis. Journal of Biological Chemistry 273 32111-32120. (https://doi.org/10.1074/ jbc.273.48.32111)

Foretz M, Pacot C, Dugail I, Lemarchand P, Guichard C, Le Liepvre X, Berthelier-Lubrano C, Spiegelman B, Kim JB, Ferre P, et al. 1999 ADD1/SREBP-1c is required in the activation of hepatic lipogenic gene expression by glucose. Molecular and Cellular Biology 19 3760-3768. (https://doi.org/10.1128/MCB.19.5.3760)

Gao Z, Hwang D, Bataille F, Lefevre M, York D, Quon MJ \& Ye J 2002 Serine phosphorylation of insulin receptor substrate 1 by inhibitor kappa B kinase complex. Journal of Biological Chemistry 277 48115-48121. (https://doi.org/10.1074/jbc.M209459200)

Guo S 2013 Molecular basis of insulin resistance: the role of IRS and Foxo1 in the control of diabetes mellitus and its complications. Drug Discovery Today Disease Mechanisms 10 e27-e33. (https://doi. org/10.1016/j.ddmec.2013.06.003)

Hajer GR, van Haeften TW \& Visseren FL 2008 Adipose tissue dysfunction in obesity, diabetes, and vascular diseases. European Heart Journal 29 2959-2971. (https://doi.org/10.1093/eurheartj/ehn387)

Hotamisligil GS, Shargill NS \& Spiegelman BM 1993 Adipose expression of tumor necrosis factor-alpha: direct role in obesity-linked insulin resistance. Science 259 87-91. (https://doi.org/10.1126/science.7678183)

Huh JY, Park YJ, Ham M \& Kim JB 2014 Crosstalk between adipocytes and immune cells in adipose tissue inflammation and metabolic dysregulation in obesity. Molecules and Cells 37 365-371. (https://doi. org/10.14348/molcells.2014.0074)

Hwang HJ, Jung TW, Hong HC, Seo JA, Kim SG, Kim NH, Choi KM, Choi DS, Baik SH \& Yoo HJ 2015a LECT2 induces atherosclerotic inflammatory reaction via CD209 receptor-mediated JNK phosphorylation in human endothelial cells. Metabolism 64 1175-1182. (https://doi.org/10.1016/j.metabol.2015.06.001)

Hwang HJ, Jung TW, Kim BH, Hong HC, Seo JA, Kim SG, Kim NH, Choi KM, Choi DS, Baik SH, et al. 2015b A dipeptidyl peptidase-IV inhibitor improves hepatic steatosis and insulin resistance by AMPKdependent and JNK-dependent inhibition of LECT2 expression. Biochemical Pharmacology 98 157-166. (https://doi.org/10.1016/j. bcp.2015.08.098)

Jager J, Gremeaux T, Cormont M, Le Marchand-Brustel Y \& Tanti JF 2007 Interleukin-1beta-induced insulin resistance in adipocytes through down-regulation of insulin receptor substrate-1 expression. Endocrinology 148 241-251. (https://doi.org/10.1210/en.2006-0692)

Lan F, Misu H, Chikamoto K, Takayama H, Kikuchi A, Mohri K, Takata N, Hayashi H, Matsuzawa-Nagata N, Takeshita Y, et al. 2014 LECT2 functions as a hepatokine that links obesity to skeletal muscle insulin resistance. Diabetes 63 1649-1664. (https://doi.org/10.2337/db13-0728)

Lu XJ, Chen J, Yu CH, Shi YH, He YQ, Zhang RC, Huang ZA, Lv JN, Zhang S \& Xu L 2013 LECT2 protects mice against bacterial sepsis by activating macrophages via the CD209a receptor. Journal of Experimental Medicine 210 5-13. (https://doi.org/10.1084/jem.20121466)

Lumeng CN, DelProposto JB, Westcott DJ \& Saltiel AR 2008 Phenotypic switching of adipose tissue macrophages with obesity is generated by spatiotemporal differences in macrophage subtypes. Diabetes $\mathbf{5 7}$ 3239-3246. (https://doi.org/10.2337/db08-0872)

Mohamed-Ali V, Goodrick S, Rawesh A, Katz DR, Miles JM, Yudkin JS, Klein S \& Coppack SW 1997 Subcutaneous adipose tissue releases interleukin-6, but not tumor necrosis factor-alpha, in vivo. Journal of Clinical Endocrinology and Metabolism 82 4196-4200. (https://doi. org/10.1210/jcem.82.12.4450)

Mottillo EP, Shen XJ \& Granneman JG 2010 beta3-adrenergic receptor induction of adipocyte inflammation requires lipolytic activation of 
stress kinases p38 and JNK. Biochimica et Biophysica Acta 1801 1048-1055. (https://doi.org/10.1016/j.bbalip.2010.04.012)

Olefsky JM \& Glass CK 2010 Macrophages, inflammation, and insulin resistance. Annual Review of Physiology 72 219-246. (https://doi. org/10.1146/annurev-physiol-021909-135846)

Olson CM, Hedrick MN, Izadi H, Bates TC, Olivera ER \& Anguita J 2007 p38 mitogen-activated protein kinase controls NF-kappaB transcriptional activation and tumor necrosis factor alpha production through RelA phosphorylation mediated by mitogen- and stress-activated protein kinase 1 in response to Borrelia burgdorferi antigens. Infection and Immunity 75 270-277. (https://doi.org/10.1128/IAI.01412-06)

Puigserver P, Rhee J, Lin J, Wu Z, Yoon JC, Zhang CY, Krauss S, Mootha VK, Lowell BB \& Spiegelman BM 2001 Cytokine stimulation of energy expenditure through p38 MAP kinase activation of PPARgamma coactivator-1. Molecular Cell 8 971-982. (https://doi. org/10.1016/S1097-2765(01)00390-2)

Saito T, Okumura A, Watanabe H, Asano M, Ishida-Okawara A, Sakagami J, Sudo K, Hatano-Yokoe Y, Bezbradica JS, Joyce S, et al. 2004 Increase in hepatic NKT cells in leukocyte cell-derived chemotaxin 2-deficient mice contributes to severe concanavalin A-induced hepatitis. Journal of Immunology 173 579-585. (https://doi. org/10.4049/jimmunol.173.1.579)

Schieven GL 2005 The biology of p38 kinase: a central role in inflammation. Current Topics in Medicinal Chemistry 5 921-928. (https://doi.org/10.2174/1568026054985902)

Shen HX, Li L, Chen Q, He YQ, Yu CH, Chu CQ, Lu XJ \& Chen J 2016 LECT2 association with macrophage-mediated killing of Helicobacter pylori by activating NF-kappaB and nitric oxide production. Genetics and Molecular Research 15. (https://doi.org/10.4238/gmr15048889)

Sinor AD \& Lillien L 2004 Akt-1 expression level regulates CNS precursors. Journal of Neuroscience 24 8531-8541. (https://doi. org/10.1523/JNEUROSCI.1470-04.2004)
Sun S, Ji Y, Kersten S \& Qi L 2012 Mechanisms of inflammatory responses in obese adipose tissue. Annual Review of Nutrition 32 261-286. (https://doi.org/10.1146/annurev-nutr-071811-150623)

Ulivi V, Giannoni P, Gentili C, Cancedda R \& Descalzi F 2008 p38/ NF-kB-dependent expression of COX-2 during differentiation and inflammatory response of chondrocytes. Journal of Cellular Biochemistry 104 1393-1406. (https://doi.org/10.1002/jcb.21717)

Weisberg SP, McCann D, Desai M, Rosenbaum M, Leibel RL \& Ferrante AW Jr 2003 Obesity is associated with macrophage accumulation in adipose tissue. Journal of Clinical Investigation 112 1796-1808. (https://doi.org/10.1172/JCI200319246)

Xu H, Barnes GT, Yang Q, Tan G, Yang D, Chou CJ, Sole J, Nichols A, Ross JS, Tartaglia LA, et al. 2003 Chronic inflammation in fat plays a crucial role in the development of obesity-related insulin resistance. Journal of Clinical Investigation 112 1821-1830. (https://doi. org/10.1172/JCI200319451)

Yamagoe S, Yamakawa Y, Matsuo Y, Minowada J, Mizuno S \& Suzuki K 1996 Purification and primary amino acid sequence of a novel neutrophil chemotactic factor LECT2. Immunology Letters 52 9-13. (https://doi.org/10.1016/0165-2478(96)02572-2)

Yamagoe S, Mizuno S \& Suzuki K 1998 Molecular cloning of human and bovine LECT2 having a neutrophil chemotactic activity and its specific expression in the liver. Biochimica et Biophysica Acta 1396 105-113. (https://doi.org/10.1016/S0167-4781(97)00181-4)

Zhang L, Keung W, Samokhvalov V, Wang W \& Lopaschuk GD 2010 Role of fatty acid uptake and fatty acid beta-oxidation in mediating insulin resistance in heart and skeletal muscle. Biochimica et Biophysica Acta 1801 1-22. (https://doi.org/10.1016/j. bbalip.2009.09.014)

Zick Y 2005 Ser/Thr phosphorylation of IRS proteins: a molecular basis for insulin resistance. Science STKE 2005 pe4. (https://doi. org/10.1126/stke.2682005pe4)

Received in final form 20 March 2018

Accepted 12 April 2018

Accepted Preprint published online 12 April 2018
(C) 2018 Society for Endocrinology Published by Bioscientifica Ltd. Printed in Great Britain 